\title{
0 wartościach i ich zmianie - raport z badań porównawczych nad systemami wartości studentów
}

\begin{abstract}
The present publication deals with the description of selected aspect of young people's mentality, i.e. their systems of values. The research was conducted three times: in 2003 (325 respondents), in 2008 (379 respondents), and in 2013 (368 respondents), and it embraced students of the Bialystok universities. An attempt was made to establish if in the period of the ten years between the three surveys, and thus with the advancement of the transformational processes in Poland, one could observe changes in the mentality in the desired direction - from the point of view of political transformations - from 'collectivism' to 'individualism'. The way of understanding values was adopted from M. Rokeach's theory. To study the system of values, the Rokeach Value Survey was used. The obtained results lead to a conclusion that together with the advancement of transformation processes, young people's systems of values undergo the transformation 'towards individualism' (except the comparison of the groups from 2008 and 2013). However, this 'individualisation' refers to a particular category of values. A growth of preferences for 'pro-developmental' values, which are essential for the system changes, was not observed. Instead, there is stronger acceptance of hedonistic values connected with the need for stimulation (an interesting,
\end{abstract}

1 Mirosława Czerniawska, Katedra Ekonomii i Nauk Społecznych, Wydział Zarządzania, Politechnika Białostocka w Białymstoku, Polska, m.czerniawska@pb.edu.pl. 
pleasant and diversified life), as well as the values connected with the social and material status. There was also an increase in the significance of collective values, which are a part of stabilizing-affiliate syndrome.

\section{Key words:}

values of youths, Rokeach's value theory, collectivism-individualism, political transformations

\section{WPROWADZENIE}

Proces transformacji ustrojowej w Polsce jest zakorzeniony w zachodniej myśli liberalnej, której konstytutywną cechę stanowi indywidualizm. W związku z tym naturalny wydawał się pogląd, że przeobrażenia mentalne społeczeństwa w kierunku indywidualizmu ułatwią funkcjonowanie w warunkach liberalnej demokracji i gospodarki rynkowej (Miszalska, 1997). Indywidualiści, czując się wolni i niezależni, postrzegają siebie jako odpowiedzialnych za własny los, koncentrują się na rozwoju własnych kompetencji i wzroście efektywności działań opartych na własnym wysiłku, potrafią „odciąć się” od tradycji i funkcjonować w złożonej, wielowątkowej kulturze (Czerniawska, 2010). Indywidualizm stoi w opozycji do kolektywizmu, który uważany jest za dominującą formę mentalności polskiego społeczeństwa w okresie transformacyjnym.

W skład pojęcia ,indywidualizm-kolektywizm” wchodzi duża liczba zmiennych, które odzwierciedlają złożoność w rozumieniu pojęcia „mentalność”. W opisie mentalności podkreśla się zazwyczaj, że jest ona charakterystycznym dla jednostki (lub klasy osób) sposobem myślenia (Reber, Reber, 2005). Odnosi się zatem do zawartości umysłu czy „obrazu myśli”. W owym „obrazie myśli” w dużym stopniu odzwierciedlają się właściwości świata zewnętrznego: kulturowe, ekonomiczne, polityczne i społeczne warunki życia. W jego skład wchodzą przekonania, ideały, wartości, skłonności, interesy i postawy, które ukierunkowują ludzkie zachowanie. Wśród wymienionych zmiennych na szczególną uwagę zasługują wartości. Są one konstruktem uświadomionym przez jednostkę, poddającym się werbalizacji, a tym samym możliwym do pomiaru (Czerniawska, 2010). Opierając się na diagnozie systemów wartości, stworzono m.in. kulturową mapę świata (Schwartz, Bardi, 2001; Schwartz, 2004), która pozwala „spojrzeć” na wartości jako atrybuty kultur.

W prezentowanych w niniejszym artykule badaniach dążono do uzyskania odpowiedzi na pytanie, jak zmiany ustrojowe, ich poziom zaawansowania (ba- 
dania przeprowadzone zostały po 15, 20 i 25 latach od rozpoczęcia procesu transformacji ustrojowej) odzwierciedlają się w treściowym aspekcie systemów wartości. Wybór wartości - jak stwierdza Gurycka (2001) - jest związany „z czasem społecznym”, w którym człowiek żyje, z kulminacją zdarzeń, faktów i znaczących osób. Ludzie (a przynajmniej znaczna ich część) przystosowują się do wymagań, nabywają nowych wartości i wcielają je w życie. Budują w swoim umyśle „nową” koncepcję świata, stosunków międzyludzkich i własnej osoby. Stabilne systemy wartości - „uporczywie” powielane z pokolenia na pokolenie w przekazie społecznym - mogą okazać się dysfunkcyjne, gdyż utrudniają człowiekowi radzenie ze zmianami w otoczeniu, zwłaszcza zaś z tymi, które sięgają podstaw ustroju (Feldman, 2008).

Doceniając rolę wartości w funkcjonowaniu społeczeństwa w okresie przeobrażeń ustrojowych, podjęto się w ciągu ostatnich 25 lat realizacji licznych badań nad tym konstruktem (przegląd badań w: Czerniawska, 2010). Starano się odpowiedzieć na pytanie, czy systemy wartości społeczeństwa polskiego są uzależnione od zmiany warunków ekonomicznych, politycznych i społecznych. W większości badań uwidoczniła się ogólna prawidłowość: wartości „stabilizacji”, takie jak: „zdrowie”, „rodzina”, „praca”, „dostatek”, dominują nad wartościami progresu i rozwoju, postępu i transformacji. Zmiana systemów wartości przebiega odmiennie w różnych grupach społecznych i zależy m.in. od takich czynników, jak wiek i poziom wykształcenia. Należy jednocześnie podkreślić, że w pracach empirycznych stosowano różnorodne podejścia teoretyczne i strategie metodologiczne, co utrudnia dokonanie charakterystyki porównawczej otrzymanych wyników. Ponadto badania prowadzone przez jednego autora za pomocą tych samych narzędzi rzadko miały charakter cykliczny, co uniemożliwia odpowiedź na pytanie, jak zmieniają się systemy wartości.

\section{PROBLEM BADAWCZY I HIPOTEZY}

Zaprezentowane w niniejszym artykule badania odnoszą się do młodego pokolenia Polaków, dotyczą jednego z wymiarów mentalności, tj. systemu wartości. Przyjęto za Rokeachem (1973) określony sposób rozmienia wartości. Wartość jest utożsamiona z pojęciem abstrakcyjnym, które jako kryterium ogólne wyznacza preferencje wobec celów (wartości ostateczne) oraz środków służących ich realizacji (wartości instrumentalne). Badania mają charakter porównawczy. Zostały przeprowadzone wśród studentów w 2003, 2008 oraz 2013 roku z wykorzystaniem tego samego narzędzia badawczego, tj. Skali Wartości Rokeacha. Starano się 
ustalić empirycznie, czy okres dziesięciu lat, w którym dokonano trzykrotnych pomiarów, jest wystarczający dla zmiany systemów wartości? Czy rzeczywiście zaobserwować można dewaluację znaczenia wartości kolektywistycznych, które to czyniły jednostkę zależną od grupy, miłującą życie „spokojne i harmonijne”, i wzrost akceptacji wartości indywidualistycznych, stymulujących motywację do osiągnięcia indywidualnego sukcesu, zdobycie statusu w oparciu o własne osiągnięcia, otwarcie na nowe idee oraz niezależność myślenia i działania, a tym samym ułatwiających dopasowanie się do nowego ustroju? Testowaniu poddana została następująca hipoteza: w im późniejszym okresie przeprowadzone były badania, tym relatywnie niższe wskaźniki preferencji uzyskiwały wartości kolektywistyczne i tym relatywnie wyższe wskaźniki preferencji - wartości indywidualistyczne.

\section{METODA BADAŃ}

Grupa badana. W badaniu wzięły udział 1072 osoby, z czego 325 (30,32\%) w 2003 roku, 379 (35,35\%) - w 2008 roku i 368 (34,33\%) - w 2013 roku. Trzy grupy były ujednolicone pod względem:

- kierunku kształcenia: około 50\% badanych stanowili studenci pedagogiki Uniwersytetu w Białymstoku i około 50\% badanych - studenci zarządzania Politechniki Białostockiej;

- trybu kształcenia: studia stacjonarne;

- poziomu kształcenia: studenci pierwszego, drugiego i trzeciego roku;

- płci: przewaga liczbowa kobiet (około 80\%);

- wieku: około 90\% badanych stanowili studenci w wieku 20-21 lat.

Tabela 1. Badana grupa

\begin{tabular}{lcrcccc}
\hline \multirow{2}{*}{$\begin{array}{l}\text { Wiek } \\
\text { (w latach) }\end{array}$} & \multicolumn{2}{c}{ Badanie z 2003 roku } & \multicolumn{2}{c}{ Badanie z 2008 roku } & \multicolumn{2}{c}{ Badanie z 2013 roku } \\
\cline { 2 - 7 } & liczebność & odsetek & liczebność & odsetek & liczebność & odsetek \\
\hline 24 & 6 & $1,85 \%$ & 10 & $2,64 \%$ & 3 & $0,82 \%$ \\
\hline 23 & 7 & $2,15 \%$ & 10 & $2,64 \%$ & 12 & $3,26 \%$ \\
\hline 22 & 22 & $6,77 \%$ & 25 & $6,60 \%$ & 30 & $8,15 \%$ \\
\hline 21 & 242 & $74,46 \%$ & 282 & $74,40 \%$ & 283 & $76,90 \%$ \\
\hline 20 & 48 & $14,77 \%$ & 52 & $13,72 \%$ & 40 & $10,87 \%$ \\
\hline
\end{tabular}

Źródło: Opracowanie własne. 
Uwzględniając przedstawioną powyżej charakterystykę trzech grup badawczych, sądzić można, że cechuje je zbliżony zakres wiedzy na temat rzeczywistości społeczno-politycznej, porównywalny poziom intelektualny, podobne - związane z kierunkiem studiów i okresem rozwojowym - zainteresowania, jak również zbliżone doświadczenia interpersonalne (charakter relacji społecznych). Różnią się one natomiast doświadczeniami związanymi z postępem procesów transformacyjnych.

Narzędzia badawcze. W badaniu wykorzystano Skalę Wartości Rokeacha (Brzozowski, 1989). W celu pomiaru relatywnej ważności wartości autor wyselekcjonował osiemnaście wartości ostatecznych oraz osiemnaście wartości instrumentalnych i umieścił na dwóch odrębnych skalach. Osoby badane zobowiązane były do uporządkowania wartości przez przypisywanie im odpowiednich rang. Rangą „1” oznaczano wartość najwyżej preferowaną, rangą „18” - wartość najniżej preferowaną.

Z punktu widzenia sformułowanego problemu badawczego konieczne jest sprecyzowanie, jakie wartości kryją się w konstelacji ,indywidualizm-kolektywizm”. Pomocne w tym zakresie były badania i analizy teoretyczne przeprowadzone przez Schwartza i Bilsky’go (1987), które objęły wartości ze Skali Rokeacha. Autorzy wskazali, że wartości są przejawem interesów indywidualnych bądź grupowych, a zatem część z 36 wartości wchodzi w skład orientacji indywidualistycznej (i należą one do takich sfer motywacji, jak: „przyjemność”, „osiągnięcia” i „kierowanie sobą”), część - w skład orientacji kolektywistycznej (i należą one do takich sfer motywacji, jak: „prospołeczność”, „ograniczenie siebie i konformizm” oraz „bezpieczeństwo”). Wyodrębnili oni także kategorię interesów mieszanych (związana jest z typem motywacji „dojrzałość” i odnosi się do wartości: „mądrość”, „o szerokich horyzontach”, „dojrzała miłość”, „świat piękna” i „odważny”) i przynależne do niej wartości uznali za niejednoznaczny identyfikator orientacji indywidualistycznej i kolektywistycznej (por. Brzozowski, 1989; Czerniawska, 2010).

W późniejszych publikacjach Schwartz (2007) opisuje wartości w dwóch dwubiegunowych wymiarach (posługuje się w tym celu stworzonym przez siebie narzędziem: Skala Wartości Schwartza zawiera większą liczbę wartości, ale wartości ze Skali Rokeacha wchodzą w jej skład). Jeden z tych wymiarów, odnoszący się do wartości „zorientowanych na jednostkę - zorientowanych na inne obiekty społeczne”, wykorzystano w ocenie poprawności podziału wartości z listy Rokeacha (por. klasyfikacja przedstawiona niżej). Za indywidualistyczne uznano te wartości, które zostały w modelu Schwartza sklasyfikowane jako „zorientowane na jednostkę” (przy czym kluczowe dla orientacji indywidualistycznej są wartości 
związane z autonomią, tj. „hedonizm”, „stymulacja” i „samodzielność”), z kolei za kolektywistyczne - te, które zostały sklasyfikowane jako „zorientowane na inne obiekty społeczne” (przy czym kluczowe dla orientacji kolektywistycznej są wartości związane z konserwatyzmem/zakorzenieniem, tj. „bezpieczeństwo”, „tradycja” i „konformizm”). Wyjątek stanowią wartości: „o szerokich horyzontach” i „świat piękna”. W rozpatrywanej wersji modelu Schwartza przynależą one do orientacji społecznej i typu wartości „uniwersalizm”, a w klasyfikacji autorki badań - do grupy wartości indywidualistycznych. Wartość „świat piękna” kojarzy się silnie z motywacją hedonistyczną, z kolei wartość „o szerokich horyzontach” ma konotacje ze sferą poznawczą i - jak inne wartości o charakterze poznawczym (np. „uzdolniony”, „intelektualista”) - wiąże się z motywacją osiągnięć (por. Czerniawska, 2010).

Ze Skali Wartości Rokeacha uznano za indywidualistyczne wartości związane z:

- statusem społecznym, prestiżem i sukcesem osobistym (w tym również materialnym): „uznanie społeczne” (o15), „poczucie własnej godności” (o7), „poczucie dokonania” (o6), ,ambitny” (i1), „dostatnie życie” (o4);

- wolnością wyboru, niezależnością myślenia i działania, kompetencją intelektualną: „,wolność” (o16), „niezależny” (i6), „odważny” (i9), „obdarzony wyobraźnią” (i7), „o szerokich horyzontach” (i11), „uzdolniony” (i17), „,intelektualista” (i3), „logiczny” (i5);

- hedonizmem i zapotrzebowaniem na stymulację (ciekawe, przyjemne, urozmaicone życie): „szczęście” (o13), „pogodny” (i12), „przyjemność” (o10), ,życie pełne wrażeń” (o18), „świat piękna” (o14).

Za kolektywistyczne uznano wartości związane z:

- ochroną dobra wszystkich ludzi oraz tych, z którymi jednostka wchodzi w bezpośrednie interakcje (dobrostan grupy, do której jednostka należy): „pokój na świecie” (o8), „równość” (o12), „pomocny” (i13), „uczciwy” (i15), „wybaczający” (i18), „kochający” (i4), „odpowiedzialny” (i8); bezpieczeństwem grup tożsamościowych i poszanowaniem tradycji/religii: „,bezpieczeństwo rodziny” (o2), „bezpieczeństwo narodowe” (o1), „zbawienie” (o17);

- wyważonymi poglądami społecznymi, harmonią intrapersonalną i interpersonalną: „mądrość” (o5), „równowaga wewnętrzna” (o11), „opanowany” (i10), „,czysty” (i2) „uprzejmy” (i16), „posłuszny” (i14), „,dojrzała miłość” (o3), „prawdziwa przyjaźń” (o9). 


\section{WYNIKI BADAŃ}

W niniejszej pracy poszukuje się odpowiedzi na pytanie, jakie wartości prezentują studenci badani w 2003, 2008 i 2013 roku oraz czy 5-10 lat jest okresem wystarczającym dla uwidocznienia się zmian w obszarze aksjologicznym? Zróżnicowanie preferencji wartości interpretowano w wymiarze „indywidualizm - kolektywizm”2.

Hierarchia wartości. Osoba porządkująca wartości wchodzące w skład Skali Rokeacha umieszcza je na osiemnastu poziomach (zarówno w przypadku wartości ostatecznych, jak i instrumentalnych), przypisując im osiemnaście kolejnych rang. Poniżej przedstawione są średnie wskaźniki preferencji wartości ostatecznych (tab. 2) i instrumentalnych (tab. 3) w trzech grupach badawczych oraz prezentacja graficzna wskazująca na miejsce poszczególnych wartości w systemie (ryc. 1 i ryc. 2).

Tabela 2. Preferencje wartości ostatecznych - analiza porównawcza wyników badań uzyskanych w 2003, 2008 i 2013 roku

\begin{tabular}{|c|c|c|c|c|c|c|c|c|c|c|}
\hline \multirow[t]{2}{*}{ Lp. } & \multirow[t]{2}{*}{$\begin{array}{l}\text { Wartości } \\
\text { ostateczne }\end{array}$} & \multirow{2}{*}{$\begin{array}{c}\begin{array}{c}\text { Ba- } \\
\text { danie } \\
2003\end{array} \\
\mathbf{n}=325 \\
\end{array}$} & \multirow{2}{*}{$\begin{array}{c}\begin{array}{c}\text { Ba- } \\
\text { danie } \\
2008\end{array} \\
\mathbf{n}=379\end{array}$} & \multirow{2}{*}{$\begin{array}{c}\begin{array}{c}\text { Ba- } \\
\text { danie } \\
2013\end{array} \\
\mathbf{n}=368\end{array}$} & \multicolumn{2}{|c|}{$\begin{array}{c}\text { porównanie } \\
2003-2008\end{array}$} & \multicolumn{2}{|c|}{$\begin{array}{c}\text { porównanie } \\
2008-2013\end{array}$} & \multicolumn{2}{|c|}{$\begin{array}{c}\text { porównanie } \\
2003-2013\end{array}$} \\
\hline & & & & & $\mathbf{w}=$ & $\mathbf{p}=$ & $\mathbf{w}=$ & $\mathbf{p}=$ & $\mathbf{w}=$ & $p=$ \\
\hline 1 & $\begin{array}{l}\text { Bezpie- } \\
\text { czeństwo } \\
\text { narodowe }\end{array}$ & $10,72 *$ & $11,73^{*}$ & $11,10^{*}$ & 2,85 & 0,004 & 2,01 & 0,044 & 0,97 & n.i. \\
\hline 2 & $\begin{array}{l}\text { Bezpieczeń- } \\
\text { stwo rodziny }\end{array}$ & 3,41 & 3,25 & 2,83 & 1,47 & n.i. & 2,03 & 0,042 & 3,53 & 0,000 \\
\hline 3 & $\begin{array}{l}\text { Dojrzała } \\
\text { miłość }\end{array}$ & 6,38 & 5,95 & 5,42 & 1,50 & n.i. & 1,41 & n.i. & 2,95 & 0,003 \\
\hline 4 & $\begin{array}{l}\text { Dostatnie } \\
\text { życie }\end{array}$ & 11,24 & 10,08 & 9,50 & 3,19 & 0,001 & 1,67 & n.i. & 4,68 & 0,000 \\
\hline 5 & Mądrość & 6,26 & 7,15 & 7,21 & 3,01 & 0,003 & 0,18 & n.i. & 3,19 & 0,001 \\
\hline 6 & $\begin{array}{l}\text { Poczucie } \\
\text { dokonania }\end{array}$ & 11,57 & 11,21 & 11,09 & 1,22 & n.i. & 0,82 & n.i. & 2,01 & 0,044 \\
\hline 7 & $\begin{array}{l}\text { Poczucie } \\
\text { własnej } \\
\text { godności }\end{array}$ & 7,15 & 7,33 & 7,95 & 0,54 & n.i. & 2,34 & 0,019 & 2,58 & 0,010 \\
\hline 8 & $\begin{array}{l}\text { Pokój na } \\
\text { świecie }\end{array}$ & 9,37 & 11,10 & 11,86 & 4,18 & 0,000 & 1,69 & n.i. & 5,98 & 0,000 \\
\hline
\end{tabular}

2 Charakterystyka porównawcza systemów wartości studentów badanych w 2003 i 2008 roku przedstwiona została w pracy: Czerniawska (2010). Fragmenty zamieszczonej tam analizy wykorzystano w niniejszym artykule. 


\begin{tabular}{|c|c|c|c|c|c|c|c|c|c|c|}
\hline \multirow[t]{2}{*}{ Lp. } & \multirow[t]{2}{*}{$\begin{array}{c}\text { Wartości } \\
\text { ostateczne }\end{array}$} & \multirow{2}{*}{$\begin{array}{c}\begin{array}{c}\text { Ba- } \\
\text { danie } \\
2003\end{array} \\
n=325\end{array}$} & \multirow{2}{*}{$\begin{array}{c}\begin{array}{c}\text { Ba- } \\
\text { danie } \\
2008\end{array} \\
n=379\end{array}$} & \multirow{2}{*}{$\begin{array}{c}\begin{array}{c}\text { Ba- } \\
\text { danie } \\
2013\end{array} \\
n=368\end{array}$} & \multicolumn{2}{|c|}{$\begin{array}{c}\text { porównanie } \\
2003-2008\end{array}$} & \multicolumn{2}{|c|}{$\begin{array}{c}\text { porównanie } \\
2008-2013\end{array}$} & \multicolumn{2}{|c|}{$\begin{array}{c}\text { porównanie } \\
2003-2013\end{array}$} \\
\hline & & & & & $\mathbf{w}=$ & $\mathbf{p}=$ & $\mathbf{w}=$ & $\mathbf{p}=$ & $\mathbf{w}=$ & $\mathbf{p}=$ \\
\hline 9 & $\begin{array}{l}\text { Prawdziwa } \\
\text { przyjaźń }\end{array}$ & 7,75 & 7,24 & 7,08 & 2,13 & 0,033 & 0,17 & n.i. & 2,47 & 0,014 \\
\hline 10 & Przyjemność & 13,27 & 12,22 & 11,79 & 3,42 & 0,001 & 1,68 & n.i. & 5,15 & 0,000 \\
\hline 11 & $\begin{array}{l}\text { Równowaga } \\
\text { wewnętrzna }\end{array}$ & 7,51 & 8,67 & 8,44 & 3,56 & 0,000 & 0,67 & n.i. & 2,94 & 0,003 \\
\hline 12 & Równość & 10,55 & 11,02 & 11,08 & 1,48 & n.i. & 0,18 & n.i. & 1,61 & n.i. \\
\hline 13 & Szczęście & 7,20 & 6,12 & 5,96 & 3,86 & 0,000 & 0,73 & n.i. & 4,48 & 0,000 \\
\hline 14 & Świat piękna & 14,05 & 14,57 & 15,19 & 1,68 & 0,093 & 2,57 & 0,010 & 4,06 & 0,000 \\
\hline 15 & $\begin{array}{l}\text { Uznanie } \\
\text { społeczne }\end{array}$ & 13,10 & 12,15 & 12,60 & 3,26 & 0,001 & 1,52 & n.i. & 1,97 & 0,049 \\
\hline 16 & Wolność & 7,47 & 7,47 & 7,10 & 0,11 & n.i. & 1,30 & n.i. & 1,45 & n.i. \\
\hline 17 & Zbawienie & 9,39 & 10,27 & 10,95 & 1,76 & 0,078 & 1,44 & n.i. & 3,15 & 0,002 \\
\hline 18 & $\begin{array}{l}\text { Życie pełne } \\
\text { wrażeń }\end{array}$ & 14,50 & 13,46 & 13,88 & 3,68 & 0,000 & 1,43 & n.i. & 2,23 & 0,026 \\
\hline
\end{tabular}

*średnie arytmetyczne rang wartości (ranga «1» - najwyższa preferencja wartości, ranga «18» - najniższa preferencja wartości); w - statystyka testu Wilcoxona dla dwóch prób niezależnych; $\mathrm{p}$ - poziom istotności statystycznej; n.i. $-\mathrm{p} \geq 0,1$

Źródło: Badania własne (dane odnoszące się do roku 2003 i 2008 pochodzą z: Czerniawska, 2010, s. 107-108).

Średnie wskaźniki preferencji wartości ostatecznych zawierają się między 2. i 16. rangą (por. ryc. 1). Wartością najwyżej cenioną w trzech grupach badawczych jest „bezpieczeństwo rodziny” i - jak należy zauważyć - wyróżnia się ona lokalizacją w całym systemie aksjologicznym. „Bezpieczeństwo rodziny” jest wartością kolektywistyczną. Można wskazać na jej funkcję wspólnotową, jako że wyraża ona dążenie do zaspokojenia potrzeb silnie powiązanych ze sobą osób.

Następne skupienie wartości lokalizuje się między 5. i 9. rangą, a więc uznać je można za wartości wysoko preferowane (ranga 9. wyznacza środek hierarchii). W skład tego skupienia wchodzą zarówno wartości kolektywistyczne: „mądrość”, „dojrzała miłość”, „równowaga wewnętrzna”, „prawdziwa przyjaźń”, jak i indywidualistyczne: „poczucie własnej godności”, „szczęście”, „wolność”.

Uwzględniając, że ranga 9. stanowi środek hierarchii, wartości wchodzące w skład następnego skupienia (między 9. i 12. rangą) należy uznać za nisko preferowane. W skupieniu tym znajdują się wartości kolektywistyczne: „zbawienie”, „pokój na świecie”, „równość”, „bezpieczeństwo narodowe”, oraz indywiduali- 


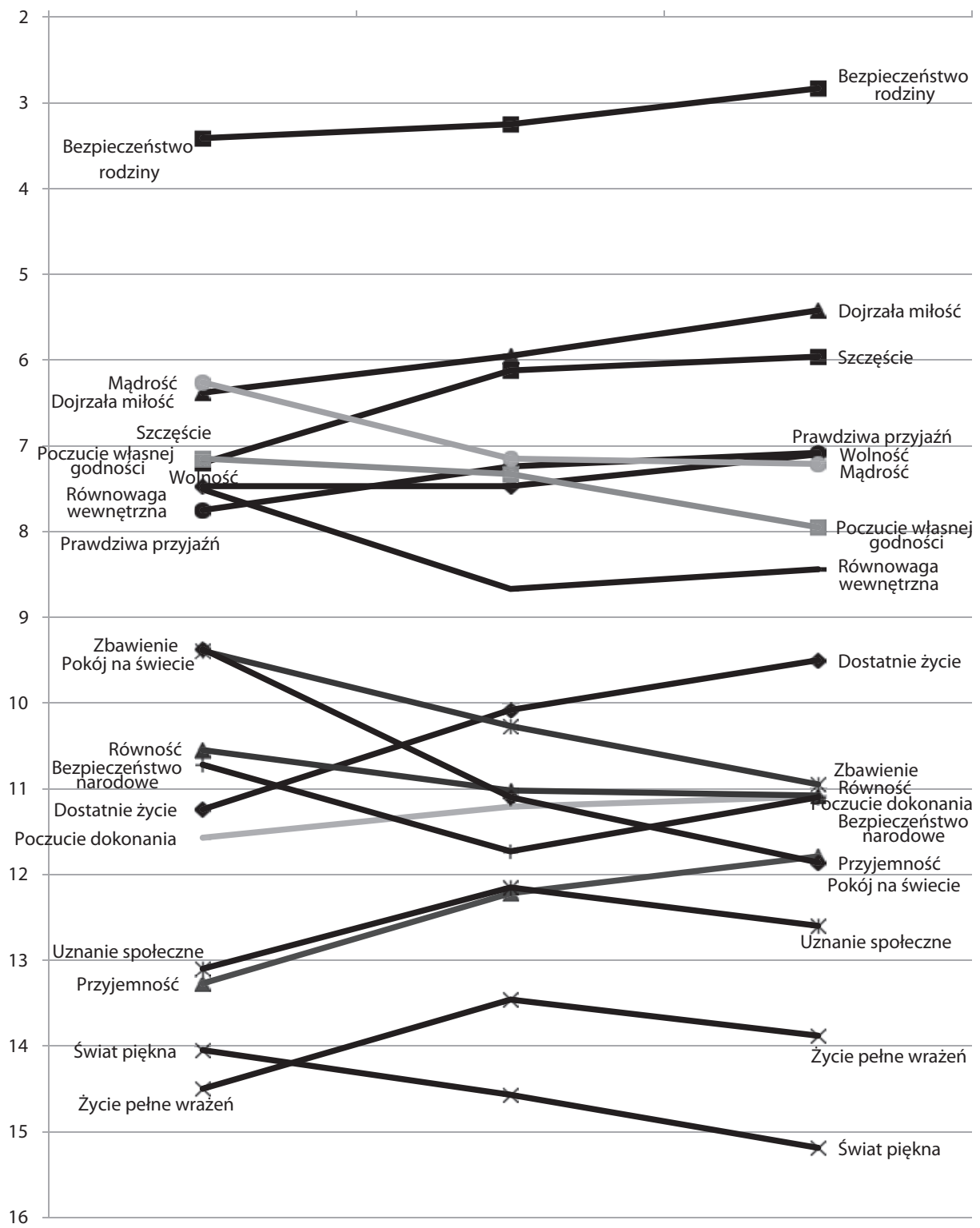

Rycina 1. Wskaźniki preferencji wartości instrumentalnych w grupach studentów badanych w 2003, 2008 i 2013 roku

Źródło: Badania własne (dane odnoszące się do roku 2003 i 2008 pochodzą z: Czerniawska, 2010, s. 109). 
styczne: „dostatnie życie”, „poczucie dokonania”. Najniższe pozycje w systemie (między 12. i 16. rangą) zajmują cztery wartości indywidualistyczne: „uznanie społeczne”, „przyjemność”, „świat piękna” i „życie pełne wrażeń”.

W skali wartości instrumentalnych wysoko cenionymi w trzech grupach studentów okazały się kolektywistyczne wartości: „kochający”, „odpowiedzialny” i „uczciwy” (por. tab. 3, ryc. 2). Wchodzą one w skład skupienia mieszczącego się między 4. i 6. rangą i odróżniają się znacznie wskaźnikami preferencji od pozostałych wartości. Relatywnie wysoko ceniona była kolektywistyczna wartość „pomocny” (7-8 ranga) i indywidualistyczna wartość „ambitny” (8-9 ranga).

Między 9. a 13. rangą lokują się wskaźniki preferencji większości wartości instrumentalnych. Są wśród nich wartości kolektywistyczne: „wybaczający”, „uprzejmy”, „opanowany” i „czysty”. W skupieniu tym znajdują się jednak przede wszystkim wartości indywidualistyczne: „,intelektualista”, „pogodny”, „, szerokich horyzontach”, „niezależny”, „odważny”, „obdarzony wyobraźnią”, „logiczny” i „uzdolniony”. Przypisuje się im pozytywne znaczenie w przemianach ustrojowych, jako że wiążą się z kompetencją intelektualną, niezależnością myślenia i działania. Najniższą pozycję w systemie stwierdzono w przypadku wartości kolektywistycznej „posłuszny” (między 14. i 16. rangą).

Tabela 3. Preferencje wartości instrumentalnych - analiza porównawcza wyników badań uzyskanych w 2003, 2008 i 2013 roku

\begin{tabular}{|c|c|c|c|c|c|c|c|c|c|c|}
\hline \multirow[t]{2}{*}{ Lp. } & \multirow{2}{*}{$\begin{array}{l}\text { Wartości } \\
\text { instrumen- } \\
\text { talne }\end{array}$} & \multirow{2}{*}{$\begin{array}{l}\text { Ba- } \\
\text { danie } \\
2003 \\
n=325\end{array}$} & \multirow{2}{*}{$\begin{array}{l}\begin{array}{l}\text { Ba- } \\
\text { danie } \\
2008\end{array} \\
n=379\end{array}$} & \multirow{2}{*}{$\begin{array}{l}\text { Ba- } \\
\text { danie } \\
2013 \\
n=368\end{array}$} & \multicolumn{2}{|c|}{$\begin{array}{l}\text { porównanie } \\
2003-2008\end{array}$} & \multicolumn{2}{|c|}{$\begin{array}{l}\text { porównanie } \\
2008-2013\end{array}$} & \multicolumn{2}{|c|}{$\begin{array}{l}\text { porównanie } \\
2003-2013\end{array}$} \\
\hline & & & & & $\mathbf{w}=$ & $p=$ & $\mathbf{w}=$ & $p=$ & $\mathbf{w}=$ & $p=$ \\
\hline 1 & Ambitny & $9,04 *$ & $8,26 *$ & $8,04 *$ & 2,202 & 0,028 & 0,49 & n.i. & 2,77 & 0,005 \\
\hline 2 & Czysty & 11,06 & 11,02 & 10,24 & 0,078 & n.i. & 2,28 & 0,022 & 2,19 & 0,028 \\
\hline 3 & Intelektualista & 8,91 & 9,79 & 9,34 & 2,224 & 0,022 & 1,16 & n.i. & 1,06 & n.i. \\
\hline 4 & Kochający & 4,26 & 4,22 & 4,52 & 0,343 & n.i. & 0,79 & n.i. & 1,07 & n.i. \\
\hline 5 & Logiczny & 11,13 & 11,45 & 10,36 & 0,674 & n.i. & 3,17 & 0,001 & 2,27 & 0,023 \\
\hline 6 & Niezależny & 9,78 & 9,66 & 10,07 & 0,379 & n.i. & 1,10 & n.i. & 0,70 & n.i. \\
\hline 7 & $\begin{array}{l}\text { Obdarzony } \\
\text { wyobraźnią }\end{array}$ & 10,82 & 11,31 & 11,87 & 1,272 & n.i. & 1,65 & n.i. & 2,82 & 0,005 \\
\hline 8 & $\begin{array}{l}\text { Odpowie- } \\
\text { dzialny }\end{array}$ & 5,37 & 5,50 & 5,83 & 0,475 & n.i. & 0,66 & n.i. & 1,12 & n.i. \\
\hline 9 & Odważny & 9,83 & 9,79 & 9,90 & 0,376 & n.i. & 0,34 & n.i. & 0,13 & n.i. \\
\hline 10 & Opanowany & 10,19 & 10,04 & 10,51 & 0,524 & n.i. & 1,43 & n.i. & 0,82 & n.i. \\
\hline 11 & $\begin{array}{l}\text { O szerokich } \\
\text { horyzontach }\end{array}$ & 9,64 & 11,23 & 11,83 & 4,278 & 0,000 & 1,61 & n.i. & 5,88 & 0,000 \\
\hline
\end{tabular}




\begin{tabular}{|c|c|c|c|c|c|c|c|c|c|c|}
\hline \multirow{2}{*}{ Lp. } & \multirow{2}{*}{$\begin{array}{l}\text { Wartości } \\
\text { instrumen- } \\
\text { talne }\end{array}$} & \multirow{2}{*}{$\begin{array}{l}\text { Ba- } \\
\text { danie } \\
2003 \\
n=325\end{array}$} & \multirow{2}{*}{$\begin{array}{l}\begin{array}{l}\text { Ba- } \\
\text { danie } \\
2008\end{array} \\
n=379\end{array}$} & \multirow{2}{*}{$\begin{array}{l}\begin{array}{l}\text { Ba- } \\
\text { danie } \\
2013\end{array} \\
n=368\end{array}$} & \multicolumn{2}{|c|}{$\begin{array}{l}\text { porównanie } \\
2003-2008\end{array}$} & \multicolumn{2}{|c|}{$\begin{array}{l}\text { porównanie } \\
2008-2013\end{array}$} & \multicolumn{2}{|c|}{$\begin{array}{l}\text { porównanie } \\
2003-2013\end{array}$} \\
\hline & & & & & $\mathbf{w}=$ & $p=$ & $\mathbf{w}=$ & $\mathbf{p}=$ & $\mathbf{w}=$ & $p=$ \\
\hline 12 & Pogodny & 9,79 & 8,78 & 9,45 & 3,022 & 0,002 & 2,05 & 0,040 & 0,97 & n.i. \\
\hline 13 & Pomocny & 7,99 & 7,88 & 6,90 & 0,593 & n.i. & 3,16 & 0,002 & 3,72 & 0,000 \\
\hline 14 & Posłuszny & 15,49 & 14,85 & 14,61 & 1,900 & 0,058 & 1,49 & n.i. & 3,40 & 0,001 \\
\hline 15 & Uczciwy & 5,72 & 5,21 & 5,47 & 1,462 & n.i. & 0,86 & n.i. & 0,63 & n.i. \\
\hline 16 & Uprzejmy & 9,81 & 9,26 & 9,15 & 1,802 & 0,071 & 0,43 & n.i. & 2,23 & 0,026 \\
\hline 17 & Uzdolniony & 12,25 & 12,09 & 12,62 & 0,535 & n.i. & 1,82 & n.i. & 1,26 & n.i. \\
\hline 18 & Wybaczający & 9,87 & 10,39 & 10,13 & 1,456 & n.i. & 0,73 & n.i. & 0,65 & n.i. \\
\hline
\end{tabular}

*średnie arytmetyczne rang wartości (ranga «1» - najwyższa preferencja wartości, ranga «18» - najniższa preferencja wartości); W - statystyka testu Wilcoxona dla dwóch prób niezależnych; $\mathrm{p}-$ poziom istotności statystycznej; n.i. $-\mathrm{p} \geq 0,1$

Źródło: Badania własne (dane odnoszące się do roku 2003 i 2008 pochodzą z: Czerniawska, 2010, s. 110).

Porównując uzyskane wyniki z zaprezentowanymi wyżej wynikami badań innych autorów, należy zauważyć, że nadal na szczycie hierarchii znajdują się wartości kolektywistyczne (wspólnotowe) o charakterze afiliacyjnym. A zatem - jak to określił Dyczewski (1995) - potrzeba posiadania bliskich osób, bezpieczeństwa i stabilizacji przedkładana jest nad potrzebę samorealizacji i ekspresji osobowości. W trzech badanych grupach, największe znaczenie posiadają wartości związane z rodziną, relacjami emocjonalnymi, wyważonymi poglądami społecznymi oraz wartości związane z ochroną dobra innych ludzi. Niższe pozycje zajmują wartości indywidualistyczne, które uznawane są za „prorozwojowe”, a więc przyczyniające się do demokratyzacji, postępu i transformacji. Jak zauważa Świda-Ziemba (1998), o „kapitalistycznej aksjologii” można mówić dopiero wtedy, gdy priorytetowymi stają się wartości aktywizujące rywalizację, konkurencję i odniesienie życiowego sukcesu, gdy najbardziej pożądanymi cechami stają się zdolności i talenty, wyróżniające jednostkę spośród innych ludzi.

Koncentrowanie się w analizach porównawczych wyłącznie na pozycjach wartości może jednak doprowadzić do błędnych wniosków. Gdy Schwartz i Bardi (2001) przeprowadzili badania międzykulturowe (reprezentatywne próbki z 13 krajów, nauczyciele z 56 krajów, studenci z 54 krajów), zdiagnozowali ponadkulturowe uporządkowanie wartości w systemie. I tak, niezależnie od kultury, przypisywano największe znaczenie wartości „życzliwość”, rozumianej jako podtrzymywanie i umacnianie pomyślności osób bliskich. Bezpodstawne zatem jest oczekiwanie, że 


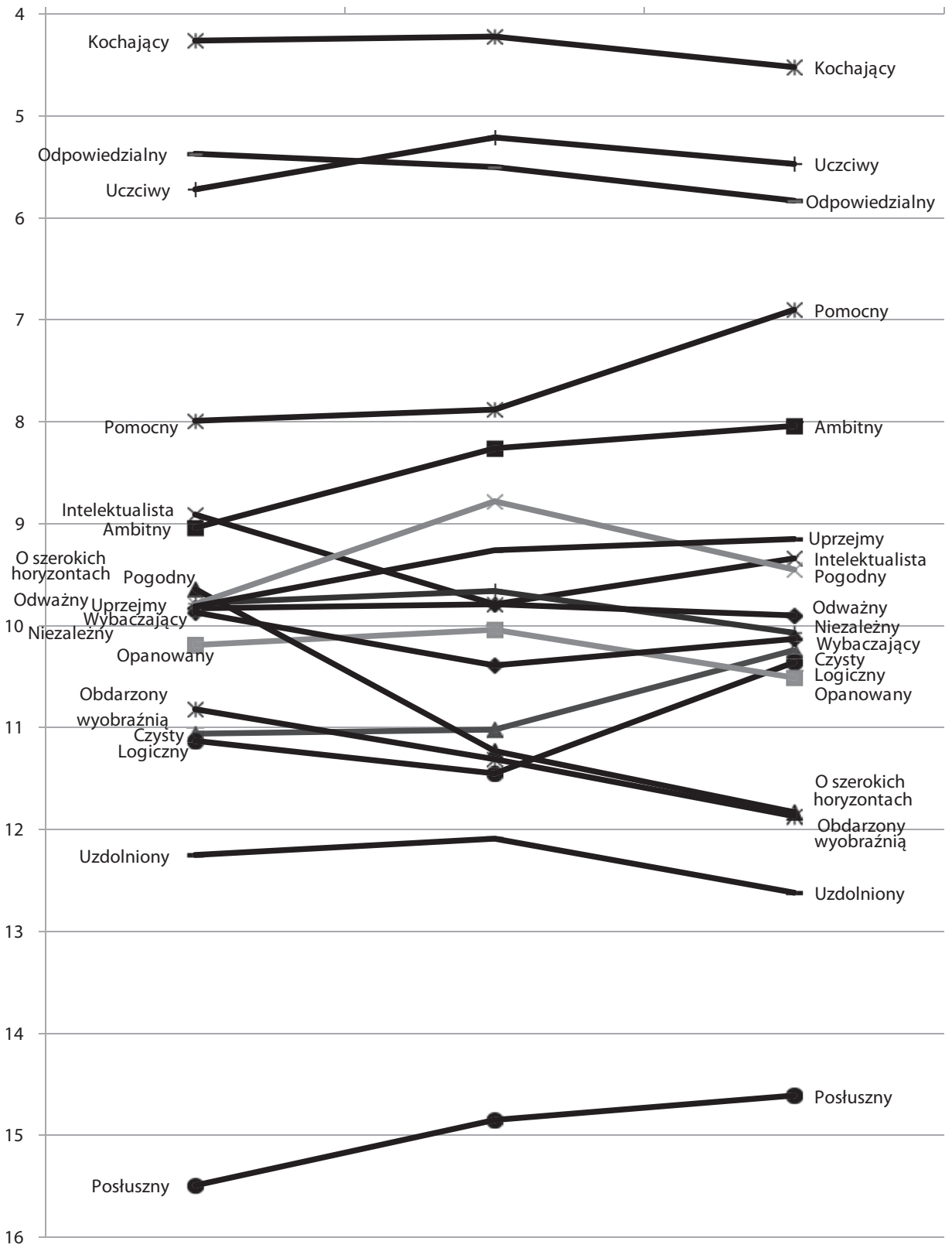

Rycina 2. Wskaźniki preferencji wartości instrumentalnych w grupach studentów badanych w 2003, 2008 i 2013 roku

Źródło: Badania własne (dane odnoszące się do roku 2003 i 2008 pochodzą z: Czerniawska, 2010, s. 111). 
wartości przynależne do tej kategorii zajmą w jakiejkolwiek grupie niskie pozycje w hierarchii, zaś wartości konstytuujące „aksjologię kapitalistyczną” - wysokie (priorytetowe). Bardziej wskazana w związku z tym jest analiza, w której ukazuje się międzygrupowe zróżnicowanie we wskaźnikach preferencji poszczególnych wartości. Takie podejście umożliwia testowanie hipotezy o zmianach w obrębie systemów wartości w kolejnych, przeprowadzanych w 2003, 2008 i 2013 roku, badaniach. Relatywne różnice w preferencjach wartości mogą ujawnić się przy podobnej ich lokalizacji w systemie.

Zróżnicowanie systemów wartości. Aby oszacować różnice między dwoma grupami z jednoczesnym uwzględnieniem kierunku zmian, zastosowano test Wilcoxona dla dwóch prób niezależnych (por. tab. 2 i 3). Analizę porównawczą wyników przeprowadzono łącznie dla skali wartości ostatecznych i instrumentalnych, uwzględniając zaprezentowany wyżej podział na wartości kolektywistyczne i indywidualistyczne.

Zgodnie z hipotezą weryfikowaną w badaniu sprawdzono, czy tracą na znaczeniu wartości kolektywistyczne. W pierwszej kolejności objęto analizą wartości kolektywistyczne związane z ochroną dobra wszystkich ludzi oraz tych, z którymi jednostka wchodzi w bezpośrednie interakcje. Okazało się, że wartości: „równość”, „kochający”, „odpowiedzialny”, „uczciwy” i „wybaczający” cechowały się podobnymi wskaźnikami akceptacji w trzech kolejnych badaniach. W przypadku wartości „pokój na świecie” odnotowano spadek preferencji, chociaż różnice nie były istotne statystycznie przy porównaniu grup z 2008 i 2013 roku. Wartość „pomocny” uzyskała wyższe wskaźniki w ostatnim badaniu w relacji do dwóch poprzednich.

Wartości kolektywistyczne związane z bezpieczeństwem grup tożsamościowych i poszanowaniem tradycji/religii to: „bezpieczeństwo rodziny”, „,bezpieczeństwo narodowe” i „zbawienie”. Ostatnią z wymienionych wartości ceniono coraz niżej w kolejnych badaniach, przy czym różnice istotne statystycznie stwierdzono, porównując grupę studentów z 2003 roku z obiema grupami badanymi w późniejszym okresie. Wzrosły natomiast wskaźniki akceptacji wartości „bezpieczeństwo rodziny” w grupie z 2013 roku w porównaniu do dwóch poprzednich. Wartość „bezpieczeństwo narodowe” była najniżej ceniona w roku 2008 w stosunku do dwóch pozostałych grup.

Wartości kolektywistyczne wiążą się także z wyważonymi poglądami społecznymi, harmonią intrapersonalną i interpersonalną. W przypadku wartości „mądrość” i „równowaga wewnętrzna” stwierdzono podobną prawidłowość: spadek preferencji przy porównaniu grupy z 2003 w relacji do dwóch pozostałych. Pozostałe wartości z tej kategorii zyskały na uznaniu, a nie - jak zakładano - 
straciły. W 2013 roku ceniona była wyżej wartość „czysty” (w stosunku do dwóch grup badanych wcześniej), „dojrzała miłość”, „prawdziwa przyjaźń”, „posłuszny” i „uprzejmy” (w stosunku do grupy badanej w 2003 roku). W przypadku trzech ostatnich wartości zaobserwowano także wzrost wskaźników akceptacji przy porównaniu grup z 2013 i 2008 roku. Wartość „opanowany” nie różniła się preferencją w trzech kolejnych badaniach.

Zgodnie z hipotezą weryfikowaną w badaniu sprawdzono, czy zyskują na znaczeniu wartości indywidualistyczne. Wartości te - jak wskazano wyżej - wiążą się z statusem społecznym, prestiżem i sukcesem osobistym (w tym również materialnym). Stwierdzono wyższe preferencje wartości: „dostatnie życie”, „uznanie społeczne” i „ambitny” w grupach badanych w 2008 i 2013 roku w porównaniu z grupą badaną w 2003 roku. Jednocześnie w ostatnim badaniu odnotowano obniżenie wskaźników preferencji wartości indywidualistycznych: „poczucie własnej godności” (w relacji do dwóch badań wcześniejszych) i „poczucie dokonania” (ale tylko w stosunku do pierwszego badania).

Wartości indywidualistyczne odnoszą się także do wolności wyboru, niezależności myślenia i działania oraz kompetencji intelektualnej. Okazało się, że wartości: „wolność”, „niezależny”, „odważny” i „uzdolniony” rangowane były na tych samych poziomach ważności w trzech kolejnych badaniach. W 2013 roku odnotowano wyższą preferencję wartości poznawczej „logiczny” (w relacji do dwóch grup badanych wcześniej), ale jednocześnie niższą - wartości „obdarzony wyobraźnią” i „o szerokich horyzontach” (w stosunku do roku 2003). W przypadku ostatniej z wymienionych wartości oraz wartości „intelektualista” stwierdzono obniżenie wskaźników akceptacji w roku 2008 w stosunku do roku 2003.

Wartości indywidualistyczne wiążą się z hedonizmem i zapotrzebowaniem na stymulację (ciekawe, przyjemne, urozmaicone życie). Jakiego rodzaju zmiany stwierdzono w tym zakresie? „Szczęście”, „przyjemność” i „życie pełne wrażeń” są wartościami zyskującymi na atrakcyjności. Grupy badane w 2008 i 2013 roku ceniły ją wyżej niż grupa z 2003 roku. Wartość „pogodny” była relatywnie wyżej ceniona w 2008 roku w stosunku do dwóch pozostałych grup. Wartość „świat piękna” uzyskiwała niższe wskaźniki preferencji w kolejnych badaniach.

\section{WNIOSKI}

1. W trzech grupach badawczych przypisuje się duże znaczenie wartościom kolektywistycznym. Wiążą się one z rodziną (,bezpieczeństwo rodziny”), ochroną dobra ludzi, harmonią interpersonalną i intrapersonalną („odpowiedzialny”, „uczciwy”, 
„pomocny”, „kochający”, „dojrzała miłość”, „prawdziwa przyjaźń”, „mądrość”, „równowaga wewnętrzna”). Stosunkowo wysoko cenione są wartości indywidualistyczne: „poczucie własnej godności”, „szczęście”, „wolność” i „ambitny” (średnie rang wymienionych wartości zawierają się w przedziale od 2 do 9). Pozostałe wartości indywidualistyczne zajmują niskie pozycje w systemie (od 9. do 16. rangi). Należy podkreślić, że wśród nich znajdują się wartości „prorozwojowe”, a więc takie, które zdaniem wielu autorów przyczyniają się do efektywnych przeobrażeń ustrojowych (Świda-Ziemba, 1998; Skarżyńska, 2005; Sawczuk, 2000).

2. Analiza treściowego aspektu systemu wartości wskazuje na bardziej indywidualistycznie zorientowany system wartości studentów badanych w 2008 roku (zwłaszcza gdy uwzględni się skalę wartości ostatecznych) niż studentów badanych w 2003 roku. Studenci badani w 2008 roku cenią wyżej wartości związane ze statusem społecznym, sukcesem materialnym i potrzebą osiągnięć („,uznanie społeczne”, „dostatnie życie”, „ambitny”), hedonizmem i zapotrzebowaniem na stymulację, tj. ciekawym, przyjemnym i urozmaiconym życiem („szczęście”, „pogodny”, „przyjemność”, „życie pełne wrażeń”). Zaobserwowano również w tej grupie wzrost preferencji nielicznych wartości kolektywistycznych, które odzwierciedlają potrzebę harmonijnych relacji między ludźmi („prawdziwa przyjaźń”, „posłuszny” i „uprzejmy”). Studenci badani w 2003 roku wyżej cenią - w stosunku do studentów badanych w 2008 roku - określone wartości kolektywistyczne. Silniejszą akceptację przejawiali oni wobec wartości związanych z bezpieczeństwem i poszanowaniem religii („pokój na świecie”, „bezpieczeństwo narodowe”, „zbawienie”), wyważonymi poglądami społecznymi i harmonią intrapersonalną („mądrość”, „równowaga wewnętrzna”). Wyższe wskaźniki preferencji uzyskały też nieliczne wartości indywidualistyczne. Odnoszą się one do kompetencji intelektualnych (,intelektualista”, „o szerokich horyzontach”) i doznań estetycznych („świat piękna”). U uwagi na fakt, że na uznaniu traciły przeważnie wartości kolektywistyczne, zaś zyskiwały - wartości indywidualistyczne można przyjąć założenia zwerbalizowane w hipotezie badawczej.

3. Następny wniosek odnosi się do porównań grup uczestniczących w badaniu w roku 2008 i 2013. W tym przypadku stwierdzono niewielkie zróżnicowanie, ale na znaczeniu zyskały wartości kolektywistyczne związane z bezpieczeństwem („,bezpieczeństwo narodowe” i „bezpieczeństwo rodziny”) oraz wartości regulujące sposoby zachowania względem bliskich sobie ludzi (,pomocny” i „czysty”). Relatywnie niżej w 2013 roku cenione były wartości indywidualistyczne, które wiążą się z szacunkiem do własnej osoby („,poczucie własnej godności”) i hedonizmem 
(„pogodny” i „świat piękna”). Jedyną wartością indywidualistyczną cenioną wyżej była poznawcza wartość „logiczny”. Uzyskane wyniki badań nie pozwalają zatem na pozytywną weryfikację hipotezy: zmiany w systemach wartości były niewielkie, zaś badana w 2013 roku młodzież była „bardziej kolektywistyczna” niż ta sprzed pięciu lat.

4. W okresie dziesięciu lat odnotowano największe zmiany w systemie wartości. W 2013 roku w porównaniu z rokiem 2003 straciły na znaczeniu wartości kolektywistyczne, które odnoszą się do kwestii religijnych (,zbawienie”) i bezpieczeństwa w skali światowej („pokój na świecie”). Obniżała się także ranga wartości związanych z potrzebą pogłębionej refleksji nad własnym życiem („mądrość”) oraz wewnętrznym spokojem („równowaga wewnętrzna”). Ciekawe jest jednak to, że duża liczba wartości kolektywistycznych zyskała na uznaniu. Odnoszą się one do jakości związku z osobami, z którymi wchodzi się w bezpośrednie interakcje, oraz dobrostanu tych osób. Coraz silniejszą akceptacją cechowały się wartości: „bezpieczeństwo rodziny”, „dojrzała miłość” i „prawdziwa przyjaźń”, jak również wartości regulujące sposoby zachowania względem bliskich sobie ludzi: „pomocny”, „uprzejmy”, „posłuszny” i „,zysty”. Jednocześnie bardziej atrakcyjna wydaje się młodzieży studiującej w 2013 niż w roku 2003 pewna kategoria wartości indywidualistycznych. Mają one z charakter hedonistyczny: „dostanie życie”, „szczęście”, „przyjemność”, „życie pełne wrażeń”, wiążą się z poważaniem społecznym i poczuciem sensu długofalowych działań: „uznanie społeczne” i „poczucie dokonania”. Wyżej ceniła także młodzież studiująca w roku 2013 wartości związane z pracowitością, aspiracjami, konsekwencją i racjonalnością: „ambitny” i „logiczny”. W przypadku zaledwie trzech wartości indywidualistycznych zaobserwowano spadek preferencji. Są to wartości poznawcze „o szerokich horyzontach” i „obdarzony wyobraźnią” oraz wartość ukazująca znaczenie szacunku do własnej osoby „poczucie własnej godności”. Uogólniając uzyskane wyniki bada,ń należy stwierdzić, że coraz bardziej atrakcyjne stają się wartości indywidualistyczne i mniej atrakcyjne wartości kolektywistyczne, co jest zgodne z treścią postawionej hipotezy. Zdiagnozowana została jednak pula wartości kolektywistycznych - odnosząca się do rodziny i bliskich relacji z innymi ludźmi oraz dobrostanu tych osób - która wydała się młodzieży studiującej jeszcze bardziej istotna w 2013 roku. Odnośnie do tych wartości nie została potwierdzona hipoteza badawcza. 


\section{PODSUMOWANIE I DYSKUSJA}

W trakcie przeobrażeń ustrojowych w Polsce straciły na znaczeniu wartości kolektywistyczne, a więc te, na których opierała się ideologia minionego systemu. Sprzyjają one realizacji celów grupowych, wiążą się z dążeniem do przystosowania społecznego i wypełniania zobowiązań względem grupy. Odzwierciedlają potrzebę bezpieczeństwa, integracji, harmonijnych związków między ludźmi i utrzymania więzi z najbliższymi. Wymogiem obecnego ustroju stały się nowe konfiguracje wartości, takie, które umożliwią zmianę mentalności w kierunku indywidualizmu (triada kapitalizm-demokracja-indywidualizm). Wartości skoncentrowane na Ja wiążą się jednak z różnymi motywacjami. Mogą mieć charakter „prorozwojowy” i odzwierciedlać dążenie do autonomii, samookreślenia, wewnętrznie sterowanej aktywności i kontroli nad własnym losem, samorealizacji, sukcesu i osiągnięć, nabywania kompetencji, doskonalenia w zakresie intelektualnym i osobowościowym. One to właśnie przyczyniają się do efektywnego funkcjonowania w nowym ustroju. Wartości indywidualistyczne mogą również ukierunkowywać dążenia hedonistyczne, związane ze szczęśliwym, dostatnim, przyjemnym, ciekawym i urozmaiconym życiem. Jak łatwo zauważyć, aktywność stymulowana przez te wartości ma zdecydowanie odmienny charakter (Czerniawska, 2010).

Porównując grupy studentów uczestniczących w badaniu w 2003, 2008 i 2013 roku, należy stwierdzić, że nie wzrasta preferencja wartości „prorozwojowych” (wyjątek stanowi wartość „ambitny” i „logiczny”), a więc tych, które są kluczowe dla przemian ustrojowych. Uwidacznia się natomiast silniejsza akceptacja wartości hedonistycznych, związanych z zapotrzebowaniem na stymulację (ciekawe, przyjemne i urozmaicone życie), oraz wartości związanych ze statusem społecznym i materialnym. Wskazują one raczej na potrzebę bogacenia się, konsumpcji i „korzystania z życia”, a nie na dążenie do rozwoju własnych kompetencji i efektywności działań. Hedonizm trudno jest uznać za psychologiczną przesłankę rozwoju kapitalizmu, jako że nie leży on u podstaw produktywności. Niemniej jednak - jak dowiedli Schwartz i Sagie (2000) - ważność wartości hedonistycznych wzrasta wraz z poziomem rozwoju socjoekonomicznego i zaawansowaniem demokracji. Dobrobyt materialny i prawo do autonomii (brak przymusu, autentyczność, niezależność od zewnętrznego otoczenia) legitymizują dążenie do przyjemności i zadowolenia z życia.

Można również zinterpretować uzyskane wyniki badań z punktu widzenia innej koncepcji. Inglehart wykazał, że cele (wartości) materialistyczne i cele (wartości) postmaterialistyczne korespondują z wartościami ostatecznymi z listy Rokeacha. Cele materialistyczne współwystępują z wyższymi preferencjami wartości: „,bezpieczeństwo rodziny”, „bezpieczeństwo narodowe” i „dostatnie życie”, cele 
postmaterialistyczne z kolei - z wyższymi preferencjami wartości: „świat piękna”, „mądrość”, „równość” i „harmonia wewnętrzna” (Brzozowski, 2007; Braithwaite i in., 1996). Przy tego rodzaju interpretacji można mówić o wzroście atrakcyjności celów materialistycznych wśród badanych, które to związane są z potrzebami przetrwania oraz bezpieczeństwa fizycznego i ekonomicznego. Przypomnijmy, że cele postmaterialistyczne wyrażają potrzeby samorealizacji i samoekspresji, a więc te, które znajdują się na szczycie hierarchii potrzeb Maslowa.

Uogólniając uzyskane wyniki badań, należy wskazać, że silniejszą orientację indywidualistyczną w systemie wartości (wyższe preferencje wartości indywidualistycznych i niższe preferencje wartości kolektywistycznych) zaobserwowano w grupie badanej w roku 2008 w porównaniu z grupą badaną w roku 2003. Porównując grupę z 2013 roku z grupą z 2008, dochodzi się jednak do innych wniosków. Obniża się dynamika zamian (systemy wartości są bardziej podobne) i obserwuje się raczej wzrost preferencji wartości kolektywistycznych. Porównanie skrajnych grup - 2003 i 2013 rok - wskazuje na najbardziej wyraźne zmiany w aspekcie ilościowym. Silniejszą akceptacją cieszą się liczne wartości indywidualistyczne, słabszą - wartości kolektywistyczne. Jest jednak pewne „ale”, ponieważ rodzina, miłość, przyjaźń oraz sposoby zachowań przyczyniające się do ich ochrony w dalszym ciągu zyskują na znaczeniu i zajmują niezmiennie najwyższe pozycje w systemie. Taka konfiguracja wartości wskazuje na „syndrom stabilizacyjno-afiliacyjny”, który zdiagnozowany został w badaniach innych autorów (Dyczewski, 1995; Ziółkowski, 2006; Budzyńska, 2008).

Uzyskane wyniki badań mogą także leżeć u podstaw bardziej ogólnych rozważań. Skłaniają do zastanowienia się, czy „podyktowana” przez transformację ustrojową zmiana mentalności w kierunku indywidualizmu ma jednoznacznie pozytywne konsekwencje? Czy nie doprowadza ona do wyzutej ze skrupułów rywalizacji, egoizmu, zamknięcia się w sobie, poczucia pustki, osamotnienia, zaniku ducha współpracy i solidarności, utraty wrażliwości na innych i perspektywy społecznej, której daleko jest do ideału autonomii, autentyczności, samospełnienia i doskonalenia wewnętrznego w ujęciu Maslowa i Ingleharta? Czy w tak szybko zmieniającym się świecie ludzie dążą do wnikliwej refleksji i poświęcają jej czas? Jak wskazują wyniki niniejszych badań, dążenie do dojrzałego rozumienia życia („mądrość”) i wyzbycie się wewnętrznych konfliktów („równowaga wewnętrzna”) tracą na znaczeniu. Coraz ważniejsze staje się natomiast dostatnie, pełne wrażeń życie, doświadczanie przyjemności i szczęścia ... tak charakterystyczne w epoce ponowoczesności. Ale czy młodzież będzie jeszcze gotowa brać na siebie wspólne obowiązki i osiągać dobro w rozszerzonej sferze publicznej tak, aby demokratyczne hasła braterstwa i równości miały sens? 


\section{Literatura:}

Braithwaite, V.A., Makaki, T., Pittelkow, Y. (1996). Inglehart’s materialism-postmaterialism concept: Clarifying the dimensionality debate through Rokeach's model of social values. Journal of Applied Social Psychology, 17 (26), s. 1536-1555. DOI: 10.1111/j.1559-1816.1996.tb00085.x.

Brzozowski, P. (1989). Skala Wartości (SW). Polska adaptacja Value Survey M. Rokeacha. Warszawa: Wydział Psychologii Uniwersytetu Warszawskiego.

Brzozowski, P. (2007). Wzorcowa hierarchia wartości. Lublin: Wydawnictwo UMCS.

Budzyńska, E. (2008). Podzielane czy dzielące? Wartości społeczeństwa polskiego. W: J. Mariański, L. Smyczek (red.), Wartości, postawy i więzi moralne w zmieniającym się społeczeństwie (s. 35-56). Kraków: Wydawnictwo WAM.

Czerniawska, M. (2010). Zmiany wartości i postaw młodzieży w okresie przeobrażeń ustrojowych. Indywidualizm versus kolektywizm. Białystok: Oficyna Wydawnicza Politechniki Białostockiej.

Dyczewski, L. (1995). Kultura polska w okresie przemian. Lublin: Towarzystwo Naukowe KUL.

Feldman, S. (2008). Wartości, ideologia i strukturalizacja postaw politycznych. W: D.O. Sears, L. Huddy, R. Jervis (red.), Psychologia polityczna (s. 435-464). Kraków: Wydawnictwo Uniwersytetu Jagiellońskiego.

Gurycka, A. (2001). Światopogląd młodzieży. Warszawa: Pracownia Testów Psychologicznych.

Miszalska, A. (1997). Psychokulturowy kontekst rozwoju kapitalizmu w Polsce. Kultura i Społeczeństwo, 4 (41), s. 57-73.

Reber, A.S., Reber, E.S. (2005). Słownik psychologii. Warszawa: Wydawnictwo Naukowe Scholar.

Rokeach, M. (1973). The nature of human values. New York: Free Press.

Sawczuk, W. (2000). Wartości preferowane przez studentów w okresie transformacji ustrojowej. Olsztyn: Wydawnictwo Uniwersytetu Warmińsko-Mazurskiego.

Schwartz, S.H. (2004). Mapping and interpreting cultural differences around the world. W: H. Vinken, J. Soeters, P. Ester (red.), Comparing culture, dimensions of culture in comparative perspective (s. 43-73). Leiden: Brill.

Schwartz, S.H., Bardi, A. (2001). Value hierarchies across cultures: Taking a similarities perspective. Journal of Cross-Cultural Psychology, 3 (32), s. 268-290. DOI: $10.1177 / 0022022101032003002$.

Schwartz, S.H., Sagie, G. (2000). Value consensus and importance. A cross-national study. Journal of Cross-Cultural Psychology, 4 (31), s. 465-497. DOI: $10.1177 / 0022022100031004003$.

Skarżyńska, K. (2005). Czy jesteśmy prorozwojowi? Wartości i przekonania ludzi a dobrobyt i demokratyzacja kraju. W: M. Drogosz (red.), Jak Polacy przegrywają. Jak Polacy wygrywają (s. 69-92). Gdańsk: GWP.

Świda-Ziemba, H. (1998). Wartości egzystencjonalne młodzieży lat dziewięćdziesiątych. Warszawa: Copyright by Hanna Świda-Ziemba i ISNS UW.

Ziółkowski, M. (2006). Zmiany systemu wartości. W: J. Wasilewski (red.), Współczesne społeczeństwo polskie. Dynamika zmian (s. 145-174). Warszawa: Wydawnictwo Naukowe Scholar. 